\title{
PENINGKATAN KETERAMPILAN BERBICARA DALAM BAHASA INGGRIS BERBASIS PARIWISATA BAGI SISWA SD DI DESA HUTARAJA
}

\author{
Meikardo Samuel Prayuda'), Putri Sari Margaret Julianty Silaban²), Pebri Hastuti' ${ }^{3)}$, Revita Yuni ${ }^{4)}$ \\ ${ }^{1)}$ Fakultas Keguruan dan Ilmu Pendidikan, Universitas Katolik Santo Thomas Medan \\ ${ }^{2)}$ Fakultas Ekonomi, Universitas Negeri Medan \\ Email: 1) meichardohanon@gmail.com, ${ }^{2}$ ellonagultom01@gmail.com, ${ }^{3)}$ pebrihastuti06@gmail.com, \\ 4) revitayuni25@gmail.com
}

\begin{abstract}
Abstrak
Penguasaan keterampilan berbicara dalam Bahasa Inggris merupakan suatu kebutuhan dasar bagi masyarakat yang mata pencahariannya mengandalkan nilai pariwisata setempat. Seperti halnya masyarakat yang tinggal di Desa Hutaraja, kebutuhan ini adalah krusial bagi mereka dalam menjajakan produk kreasi mereka kepada turis-turis yang datang terlebih turis-turis mancanegara yang kerap datang mengunjungi Desa Hutaraja. Namun sayangnya, peluang ini harus dihadapkan dengan masyarakat setempat yang justru tidak memiliki keterampilan berbicara dalam Bahasa Inggris. Permasalahan ini mendorong dilakukannya pelatihan ini. Adapun hasil dari pelatihan yang dilakukan telah berhasil memberikan dampak positif terhadap keterampilan dasar masyarakat berbicara dalam Bahasa Inggris. Namun demikian, perlu dilakukan pelatihan lanjutan dalam upaya penguatan keterampilan berbicara dalam Bahasa Inggris untuk masyarakat setempat agar masyarakat memiliki wawasan serta keterampilan yang lebih baik lagi dalam berkomunikasi dengan turis-turis mancanegara yang berkunjung ke Desa Hutaraja.
\end{abstract}

Kata kunci: Pelatihan; Keterampilan Dasar; Berbicara; Bahasa Inggris

\begin{abstract}
English language speaking mastery is a basic need for people who rely on the tourism sector. Just like people who live in Hutaraja, this need is crucial to them in selling their creation to the tourists moreover to the foreign tourist who often visit Hutaraja. Sadly, this chance must be faced by the people of Hutaraja who do not master any English language speaking mastery. This problem encouraged to the implementation of this training. This training had given positive result to Hutaraja's people English language speaking mastery. However, further training is needed in order to enhance English language speaking mastery of people in Hutaraja so that they can have better insight and better English language speaking mastery in communicating with foreign tourists who visit Hutaraja.
\end{abstract}

Keywords: Training; Basic Skills; Speaking; English 


\section{PENDAHULUAN}

Bahasa Inggris merupakan Bahasa internasional yang digunakan di kebanyakan negara termasuk Indonesia. Peran Bahasa Inggris sendiri tidak terpisahkan dari kehidupan bermasyarakat baik dari sektor Pendidikan, ekonomi, dan sosial. Ketiga sektor tersebut berkaitan erat dalam kaitannya dalam pengembangan sumber daya manusia yang tepat guna.

Hutaraja merupakan suatu destinasi pariwisata yang sedang dikembangkan untuk menjadi destinasi wisata bertaraf internasional. Pengembangan destinasi wisata ini diinisiasi oleh UNIKA Santo Thomas dalam tujuannya untuk melestarikan kebudayaan daerah setempat sebagai bentuk kepedulian UNIKA Santo Thomas terhadap pelestarian budaya daerah di Indonesia terkhusus di Sumatera Utara.

Salah satu bentuk nyata dari kepedulian UNIKA Santo Thomas terhadap pengembangan destinasi wisata di desa Hutaraja adalah telah terciptanya "Kampung Inggris" yang diharapkan dapat menjadi salah satu ikon yang dapat menarik perhatian wisatawan nasional terlebih internasional. Dalam pelaksanaannya, UNIKA Santo Thomas memfasilitasi segala bentuk kegiatan terkait pengembangan "Kampung Inggris". Hal ini tentunya diharapkan sebagai salah satu jalan dalam mewujudkan Desa Hutaraja sebagai salah satu situs pariwisata bertaraf internasional.

Namun sayangnya, UNIKA Santo Thomas harus dihadapkan kepada permasalahan mendasar dalam mewujudkan tujuan tersebut diatas. Disadari bahwa masyarakat di Desa Hutaraja merupakan masyarakat suku asli dan minim pengetahuan terhadap penguasaan Bahasa Inggris. Masalah lain juga timbul dimana kurangnya motivasi siswa untuk belajar Bahasa Inggris terlebih untuk berbicara dalam Bahasa Inggris. Hal ini tentunya menjadi hal yang patut untuk diperhatikan dimana pada dasarnya, pembentukan suatu situs internasional tidak terlepas dari penguasaan Bahasa Inggris sebagai Bahasa internasional yang digunakan oleh masyarakat internasional.

Menyadari permasalahan yang ada, PkM ini ditujukan untuk memberikan pelatihan dasar keterampilan berbicara dalam Bahasa Inggris berbasis Pariwisata bagi siswa SD Desa Hutaraja. Role Play diharapkan sebagai suatu stimulus dalam memotivasi siswa untuk mau berbicara dalam Bahasa Inggris. Melalui PkM ini, siswa SD Desa Hutaraja diharapkan memiliki keterampilan dasar berbicara dalam Bahasa Inggris berbasis Pariwisata.

\section{BAHAN DAN METODE}

Pengabdian pada masyarakat ini bertujuan untuk memberikan pelatihan keterampilan dasar berbicara dalam Bahasa Inggris berbasis pariwisata kepada siswa SD di Desa Hutaraja. Keterampilan yang dimaksud merupakan kemampuan Speaking yang merupakan salah satu dari empat skill dalam penguasaan Bahasa Inggris. Speaking sendiri memegang peran penting dalam kaitannya terhadap komunikasi sehari-hari baik formal maupun non-formal. Kemampuan ini merupakan yang mendasar dan terpenting khususnya bagi penduduk Desa Hutaraja dalam kaitannya dengan kepariwisataan. Secara harfiah, Speaking dapat diartikan sebagai kemampuan mentransfer pemikiran kita kedalam bentuk bunyi untuk kemudian dipahami oleh lawan bicara kita. Lebih jauh, speaking dapat diartikan sebagai aktivitas mengutarakan atau mengekspresikan pendapat yang ingin kita utarakan atau ekspresikan.

Adapun metode pelatihan yang diterapkan pada pengabdian pada masyarakat ini adalah dengan menggunakan metode ceramah, tanya jawab, dan role play atau bermain peran. Metode ceramah pada pengabdian masyarakat ini ditujukan dalam menjelaskan dasar-dasar yang perlu di pahami serta di kuasai oleh para peserta pelatihan dalam upaya menguasai keterampilan dasar berbicara dalam Bahasa Inggris atau speaking. 
Melalui metode ceramah ini, para peserta pelatihan akan memahami dasar-dasar serta pengetahuan-pengetahuan yang mereka perlukan dalam menguasai kemampuan speaking. Pengetahuan-pengetahuan dasar yang diajarkan kepada para peserta pelatihan merupakan kosa kata dasar serta lazim digunakan dalam speaking yang biasa di ucapkan sehari-hari dalam kegiatan "Speaking for Daily Activity". Dalam prakteknya, penyelenggara pelatihan akan memberikan beberapa kosa kata dalam bahasa Inggris melalui selembar kertas. Para peserta pelatihan kemudian mengikuti instruksi penyelenggara pelatihan dengan mengikuti cara membaca kosa kata tersebut dengan tepat dan benar. Para peserta pelatihan kemudian diminta untuk menghapalakan kosa kata tersebut.

Sampai pada titik ini, penyelenggara pelatihan kemudian menerapkan metode tanya jawab. Fungsi utama penerapan metode tanya jawab ini adalah untuk memastikan para peserta pelatihan benar-benar telah menghapal materi ajar yang diberikan berupa kosa kata Bahasa Inggris. Metode ini dilakukan dengan cara penyelenggara pelatihan menanyakan kemasing-masing peserta pelatihan arti dari kosa kata yang diucapkannya. Kosa kata tersebut tentunya merupakan kosa kata yang sedang mereka pelajari. Proses ini dapat dilakukan dengan penerapan Indonesian-English Translation atau sebaliknya English-Indonesian Translation pada level Word to Word Translation. Jika peserta pelatihan dirasa sudah mampu menghafalkan kosa kata tersebut, selanjutnya para peserta pelatihan dilatih untuk menggunakan kosa kata tersebut dalam kalimat sederhana berbahasa Inggris. Kalimat-kalimat tersebut merupakan kalimat sederhana yang telah dipersiapkan sebelumnya berkaitan dengan kepariwisataan. Kalimat-kalimat tersebut juga telah disusun dan dipersiapkan sedemikian rupa untuk menunjang metode pembelajaran berikutnya yaitu Role Play.

Metode Role Play atau bermain peran merupakan salah satu metode pembelajaran yang banyak digemari siswa dalam belajar bahasa. Pada prakteknya, peserta Role Play akan mempraktekkan suatu dialog yang berisi beberapa peran yang menarik. Guru diharapkan kreatif dalam mempersiapkan Role Play ini. Disatu sisi, Role Play bias jadi sangat tidak efektif bilamana dialog Role Play sangat membosankan.

Pada pelatihan ini, penyelenggara telah menyiapkan dialog Role Play yang menarik dan berkaitan dengan kepariwisataan. Dialog tersebut merupakan dialog antara seorang turis dan seorang pemandu wisata. Dialog ini dirasa tepat untuk dijadikan sebagai bahan pelatihan mengingat besar kemungkinan masyarakat setempat untuk menjadi pemandu wisata untuk desa mereka sendiri.

Materi pelatihan yang digunakan adalah dialog singkat berbasis pariwisata yang akan berguna bagi para peserta pelatihan dalam kegiatan mereka sehari-hari dalam menghadapi para wisatawan yang datang. Pelaksanaan pengabdian pada masyarakat ini dilaksanakan selama tiga hari yaitu pada tanggal $11 \mathrm{~s} / \mathrm{d} 13$ Februari 2020. Adapun rincian kegiatan tersebut adalah sebagai berikut:

Sasaran pengabdian ini merupakan siswa SD di Desa Hutaraja. Pemilihan khalayak sasaran ini dianggap sangat strategis dengan mempertimbangkan: Tingkat SD merupakan tingkat Pendidikan dimana motivasi serta pembangunan karakter diri masih sangat mudah dilakukan sehingga keberlangsungan pengabdian ini tidak hanya berhenti ketika pengabdian selesai dilakukan namun juga siswa akan memiliki motivasi atau ketertarikan untuk menggali lebih jauh lagi mengenai keterampilan dasar berbicara dalam Bahasa Inggris.

Metode yang akan digunakan dalam kaitannya dengan pelaksanaan kegiatan pengabdian kepada masyarakat ini adalah sebagai berikut:

1. Ceramah

2. Tanya Jawab 


\section{Role Play}

\section{HASIL DAN PEMBAHASAN}

Hutaraja merupakan salah satu desa yang ada di kecamatan Dolok Sanggul, Kabupaten Humbang Hasundutan, provinsi Sumatra Utara, Indonesia. Desa ini dikenal dengan desa tenun dimana para pengunjung ataupun wisatawan yang berkunjung ke desa ini akan melihat sajian alat tenun dan para penenun ulos di hamper setiap halaman rumah desa ini. Selain terkenal karena tenunnya, desa Hutaraja juga dikenal dengan mayoritas hunian penduduknya yang masih sangat tradisional. Masyarakat disana umumnya masih berhunikan rumah adat batak dimana salah satu dari sekian banyak rumah adat batak itu merupakan rumah adat batak yang diperkirakan sudah berusia 400 tahun.

Pengabdian pada masyarakat ini bertujuan untuk memeberikan pelatihan keterampilan dasar berbicara dalam Bahasa Inggris berbasis pariwisata kepada siswa SD di Desa Hutaraja. Adapun metode pelatihan yang diterapkan pada pengabdian pada masyarakat ini adalah dengan menggunakan metode ceramah, tanya jawab, dan role play atau bermain peran. Materi pelatihan yang digunakan adalah dialog singkat berbasis pariwisata yang akan berguna bagi para peserta pelatihan dalam kegiatan mereka sehari-hari dalam menghadapi para wisatawan yang datang. Pelaksanaan pengabdian pada masyarakat ini dilaksanakan selama tiga hari yaitu pada tanggal $11 \mathrm{~s} / \mathrm{d} 13$ Februari 2020. Adapun rincian kegiatan tersebut adalah sebagai berikut:

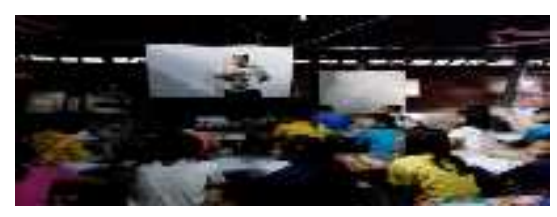

Gambar 1. Kegiatan Pelatihan di Kampung Inggris Hutaraja

\section{Hari Pertama (11 Februari 2020) Pembukaan}

1. Mengucapkan salam pembuka.

2. Mengawali dengan Doa.

3. Melakukan apersepsi.

\section{Inti}

1. Memberikan beberapa kosakata berkaitan dengan pariwisata.

2. Membaca bersama kosakata tersebut sekaligus memperbaiki pengucapan para siswa.

3. Mengajarkan arti dari kosakata tersebut dalam Bahasa Indonesia.

4. Siswa masing-masing menghafalkan kosakata tersebut beserta artinya sekaligus ejaannya dalam Bahasa Inggris.

5. Penulis melakukan tanya jawab terkait kosakata yang telah dihafalkan.

\section{Penutup}

1. Memberikan motivasi kepada para siswa agar lebih termotivasi dalam mengikuti pembelajaran serta menumbuhkan minat belajar yang lebih kuat dalam belajar Bahasa Inggris.

2. Membagikan snack.

3. Menutup dengan Doa.

4. Mengucapkan salam penutup.

\section{Hari Kedua (12 Februari 2020) \\ Pembukaan}

1. Mengucapkan salam pembuka.

2. Mengawali dengan Doa.

3. Melakukan apersepsi.

\section{Inti}

1. Melakukan eksplorasi, elaborasi, dan konfirmasi terkait pembelajaran sebelumnya.

2. Penulis memotivasi siswa untuk membuat kalimat sederhana menggunakan kosakata yang telah mereka pelajari sebelumnya dalam Bahasa Inggris.

3. Penulis memberikan contoh kalimat sederhana menggunakan kosakata yang telah mereka pelajari sebelumnya dalam Bahasa Inggris.

4. Penulis memberikan sebuah kosakata acak dari kosakata yang telah mereka pelajari dihari pertama untuk kemudian 
dibuat kedalam sebuah kalimat sederhana secara spontan.

5. Penulis memperbaiki kalimat yang masih kurang tepat.

\section{Penutup}

1. Memberikan motivasi kepada para siswa agar lebih termotivasi dalam mengikuti pembelajaran serta menumbuhkan minat belajar yang lebih kuat dalam belajar Bahasa Inggris.

2. Membagikan snack.

3. Menutup dengan Doa.

4. Mengucapkan salam penutup.

\section{Hari Ketiga (13 Februari 2020) \\ Pembukaan}

1. Mengucapkan salam pembuka.

2. Mengawali dengan Doa.

3. Melakukan apersepsi.

\section{Inti}

1. Melakukan eksplorasi, elaborasi, dan konfirmasi terkait pembelajaran sebelumnya.

2. Mendistribusikan lembar percakapan berbasis pariwisata kepada para siswa.

3. Menerjemahkan bersama arti dari percakapan tersebut.

4. Membaca percakapan tersebut bersama.

5. Memperbaiki pengucapan para siswa.

6. Melibatkan siswa dalam kegiatan role play atau bermain peran untuk mempraktekkan percakapan tersebut bersama temannya.

\section{Penutup}

1. Memberikan motivasi kepada para siswa agar lebih termotivasi dalam mengikuti pembelajaran serta menumbuhkan minat belajar yang lebih kuat dalam belajar Bahasa Inggris.

2. Membagikan snack.

3. Menutup dengan Doa.

4. Mengucapkan salam penutup.

Berikut merupakan beberapa factor pendorong dalam pelaksanaan pengabdian pada masyarakat ini:

1. Masyarakat Desa Hutaraja sangat antusias dengan adanya kunjungan yang dilakukan oleh penulis dalam kaitannya dengan pelaksanaan pengabdian pada masyarakat di desa mereka.

2. Kepala desa setempat mendukung program pengabdian pada masyarakat yang dilakukan di Desa Hutaraja dan terbuka untuk program serupa yang dapat meningkatkan taraf mutu Pendidikan masyarakat di Desa Hutaraja.

3. Antusiasme dan semangat belajar para siswa dan bahkan masyarakat dewasa dalam pelaksanaan pelatihan penguasaan keterampilan berbicara dalam Bahasa Inggris bagi siswa SD di Desa Hutaraja.

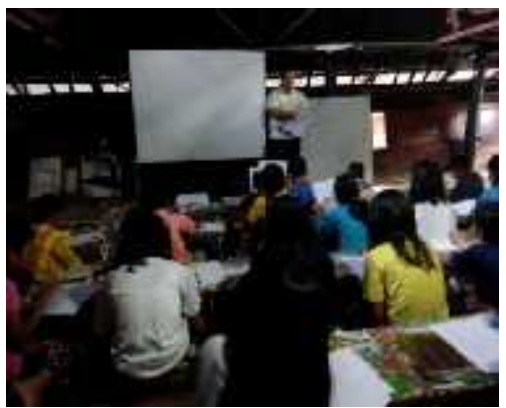

Gambar 2. Pendistribusian Bahan Ajar

Tidak ditemukan adanya factor penghambat dalam pelaksanaan kegiatan pengabdian pada masyarakat ini. Pelaksanaan pengabdian pada masyarakat ini mendapat sambutan baik dan diharapkan untuk dapat berjalan secara berkesinambungan.

Adapun hasil evaluasi dari kegiatan pengabdian pada masyarakat ini adalah sebagai berikut:

1. Siswa mampu meningkatkan kosakata dalam Bahasa Inggris berbasis pariwisata.

2. Siswa mampu membuat kalimat sederhana menggunakan kosakata dalam Bahasa Inggris berbasis pariwisata secara spontan.

3. Siswa mampu mempraktekkan role play percakapan Bahasa Inggris berbasis pariwisata dengan pengucapan serta bahasa tubuh yang baik. 
4. Siswa mampu menguasai dasar keterampilan berbicara dalam Bahasa Inggris berbasis pariwisata dengan baik.

5. Siswa memilki motivasi belajar yang tinggi dalam mengikuti pelatihan keterampilan berbicara dalam Bahasa Inggris berbasis pariwisata.

\section{KESIMPULAN}

Berikut merupakan simpulan hasil kegiatan pengabdian pada masyarakat ini:

1. Siswa memiliki kemampuan dasar berbicara dalam bahasa Inggris berbasis pariwisata.

2. Siswa memiliki motivasi belajar yang lebih besar setelah mereka mampu berbicara dalam bahasa Inggris berbasis pariwisata.

Berikut merupakan saran yang dapat diberikan untuk peningkatan kemampuan siswa agar semakin baik lagi berbicara dalam bahasa Inggris berbasis pariwisata:

1. Siswa disarankan agar sering mungkin menggunakan Bahasa Inggris dalam percakapannya sehari-hari untuk meningkatkan kemampuan berbahasa Inggris yang lebih baik.

2. Siswa disarankan agar lebih sering mendengarkan percakapan berbahasa Inggris baik dari guru, media elektronik, maupun orang disekitarnya jika memungkinkan untuk menambah kosakata serta pengalaman berbahasa Inggris yang lebih baik.

\section{DAFTAR PUSTAKA}

Badan Standar Nasional Pendidikan. (2007). Model silabus dan rencana pelaksanaan pembelajaran mata pelajaran Bahasa Inggris SMP/MTs. Jakarta: Departemen Pendidikan Nasional.

O'Bannon, B. (2008). What is a Lesson Plan?. Innovative Technology Center: The University of Tennessee.

Permendikbud Nomor 104 Tahun 2014 tentang Penilaian Hasil Belajar oleh Pendidik pada Pendidikan Dasar dan Pendidikan Menengah Pasal 7

Scarborough, R; Zellou, G (2013). Clarity in communication: "clear" speech authenticity and lexical neighborhood density effects in speech production and perception. doi:10.1121/1.4824120 
